ARTIKEL

\title{
TENOR CONFIGURATIONS IN CAMPAIGN SPEECHES OF TWO DEMOCRATIC PARTY PRESIDENTIAL CANDIDATES 2016
}

Disusun dan Diajukan oleh:

Yeni Novita Sari

NIM. 2121220011

Telah diverifikasi dan dinyatakan memenuhi syarat untuk diunggah pada jurnal online

Medan, Agustus 2017

Menyetujui

Dosen Pembimbing I

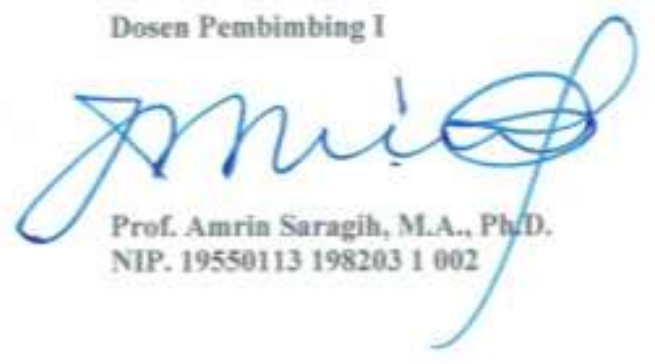

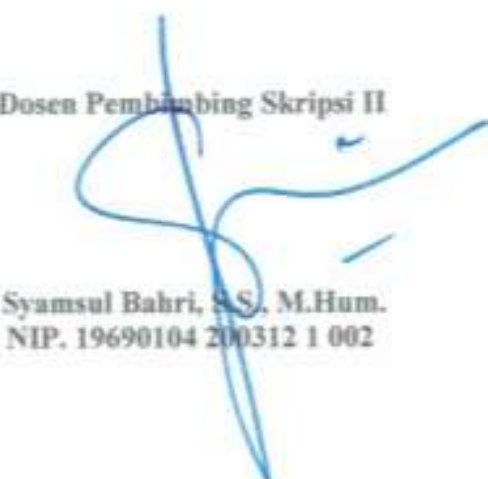

Syamsul Bahri, \&S. M.Hum. NIP. 196901042003121002

Ketua Prodi Sastra Inggris

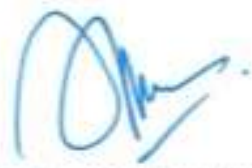

Juli Rachmadani Hasibuan, S.S., M.Hum. NIP. 198207112008012008 


\title{
TENOR CONFIGURATIONS IN CAMPAIGN SPEECHES OF TWO \\ DEMOCRATIC PARTY PRESIDENTIAL CANDIDATES 2016
}

\author{
*Yeni Novita Sari \\ **Prof. Amrin Saragih, M. A., Ph.D \\ **Syamsul Bahri, S.S., M.Hum
}

\begin{abstract}
Sari, Yeni Novita. 2121220011. Tenor Configurations in Campaign Speeches of Two Democratic Party Presidential Candidates 2016. A Thesis. English and Literature Department. Faculty of Languages and Arts. State University of Medan. 2017.
\end{abstract}

This study aims at finding out the tenor configurations that exist in the campaign speeches of two Democratic Party presidential candidates 2016 by using four aspects of tenor and it is to find out how the way the social relationship is played by addressee and addresser in political arena. Tenor configurations in campaign speeches of two Democratic Party presidential candidates is done by theory of Systemic Functional Linguistics. The use of tenor is purposed to make readers understand the speech easily and persuade the readers to do something as the speech means. This research used descriptive quantitative method. The data of this study were taken from some sources in the internet. The data were the transcripts of four campaign speeches by two Democratic presidential candidates that were delivered in different places. The writer focused on the analysis of aspects of tenor in campaign speeches by two Democratic Party presidential candidates; Hillary Clinton and Bernie Sanders, and finally found the most dominant configuration that appears in the campaign speeches. The writer found that from the four aspects of tenor the campaign speeches mostly used configuration [Formal/Equal/Positive/Infrequent].

Keywords : Tenor Configurations, Campaign Speeches, Presidential Candidates 


\section{INTRODUCTION}

As a social being, human can not live alone; they need to interact with other people in fulfilling their need. That is the reason why people use language, because language is a network of relationship. Based on systemic functional linguistic, language has three broad functions in human life, namely to describe or draw, to exchange, and to organize experience. The use of language to interact is said to exchange experience.

When using language to interact with other, people will try to find words that are fit with the situation in order to avoid miscommunication so the massage can be delivered well. Context of situation (register) is concerned with the variables of field, tenor and mode. Considering these three variables, Halliday is making a claim that of all the things going on in a situation at a time of language use, these three variables have a direct and significant impact on the type of language that will be produced. It implies that language varies according to context of situation (Eggins:2004).

Hillary Clinton and Bernie Sanders are two of Democratic Party presidential candidates 2016 in the United States. They are two leading candidates who have been competing in the series of presidential primary elections and caucuses to get Democratic's presidential nomination. In order to win the Democratic's nomination, either Hillary Clinton or Bernie Sanders needs to convince citizen that he or she is the right president to be so people will vote for him or her in the series of primary 
election and caucus. One of the ways they interact and convince people is through campaign speech.

This study attempts to apply one of the three types of situational context of analysis, it is tenor. In this analysis, tenor will be discussed in campaign speeches of those two Democratic Party presidential candidates. Hillary Clinton and Bernie Sanders have already conveyed campaign speeches in some different occasions and different states. It is interesting to see social relationship between these two Democratic presidential candidates 2016 and the listeners from different states, their roles and statuses in political arena that take a part of determining the language used in the campaign speeches.

Tenor analysis has been placed under the discussion of the interpersonal meaning. It deals with the interaction between the speaker and listener; influence behavior of speakers and how the speaker shows their point of view. Simply, tenor examines how participant cooperates with another participant to maintain the communication process in order to deliver the massage well.

The writer was interested in discussing tenor because through analyzing tenor can be found how the speakers influence their listeners. The author selects Hillary Clinton and Bernie Sanders as an object for her thesis because they are great politicians who become two leading candidates of Democratic Party for Presidential nominee of United States 2016. They possibly will make a significant change in society and bring big influence in political arena of United States. 


\section{REVIEW OF LITERATURE}

People will produce text when they communicate as a product of social process, either verbal or nonverbal process. Every text must have context. Context can be defines as anything that accompanies the text. Context can be divided into two; linguistic context and non-linguistic context. Linguistic context refers to the context within the discourse, that is, the relationship between the words, phrases, sentences and even paragraphs (Song:2010). In Systemic Functional Linguistics, non-linguistic context or the external context is termed as social context. Thus any, physical environment is seen, realized or interpreted in relation to human beings or simply termed as social context (Saragih:2014).

The social context of the text covers a wide range of area in SFL, it is interpreted as being constituted by three elements, namely context of situation (register), culture (genre) and ideology (Martin:1992). Thus, the three elements of social context are realized in language as they are properties of society.

Situational context or context of situation refers to the environment, time and place, etc. in which the discourse occurs, and also the relationship between the participants (Song:2010). Context of situation is technically termed as register that is variety of language that varies according to the use of language in different situation. It is different with dialect which is language variety based on the users.

Furthermore, context of situation is constituted by three aspects namely mode, field, and tenor (Halliday:2002). Tenor is the relationship between people involved in the communication, both in general and moment by moment (Thompson:2014). It 
means that tenor focuses on human being as the participants and their relationship in the interaction. (Saragih: 2014) states that tenor is configured by four aspects namely status or power, the level of formality, affective relations, and frequency of contact between the addresser and addressee.

\section{(1) Formality}

Formality refers to manners related to situation in which the interaction occurs. The situation where participants interact could be formal or informal. A formal situation is one where manners of interaction are predetermined and an informal situation is one where no manners of interaction are predetermined.

\section{(2) Status}

Status refers to power relationship of participants in the interaction. Power can be seen as the ability to force others. Someone has power if he can make others do or not do what he wants. The status of the tenor can be equal or unequal.

\section{(3) Affect}

Affect indicates arousals in emotional aspect of the participants in the interaction. Specifically it indicates whether participants in that interaction like or dislike one another. Affect can also be positive affect and negative affect.

\section{(4) Contact}

Contact refers to the frequency of interaction that can be frequent or infrequent. The frequent contact means that participants have done some interactions. On the other hand infrequent contact shows that the participants seldom do interaction or have just done the first contact. 


\section{RESEARCH METHODOLOGY}

This study was conducted to analyze speech by using discourse analysis focused on tenor by applying descriptive qualitative research. Descriptive qualitative research is the research whose findings are not gained through statistics procedure or other counting procedure (Strauss and Corbin: 2003).

In this study, the purpose was to describe relationship between participants in campaign speeches of two Democratic presidential candidates 2016; Hillary Clinton and Bernie Sanders through tenor configurations namely formality, status, affect, and contact. The source of data was a given data. It means that the researcher had copying the campaign speeches in the form of transcripts, not recording files. The transcripts of Hillary Clinton and Bernie Sanders' campaign speeches that became the source of data in this study were taken from the internet as follow :

1. Speech by Hillary Clinton at a Women for Hillary grassroots organizing meeting in Columbus, Ohio on January, 312016.

2. Speech by Hillary Clinton in "Get Out The Vote" event Manhattan, New York on April 20, 2016.

3. Speech by Bernie Sanders for Annoucing Candidacy for President in Burlington, Vermont on May, 262015.

4. Speech by Bernie Sanders in Los Angeles, California on Juny 08, 2016. 


\section{DATA AND DATA ANALYSIS}

As mentioned in the previous chapter, the data of this research were taken from internet. There were four transcripts of Hillary Clinton and Bernie Sanders' campaign speeches. The tenor configurations are summarized in the system network as presented in the following picture.

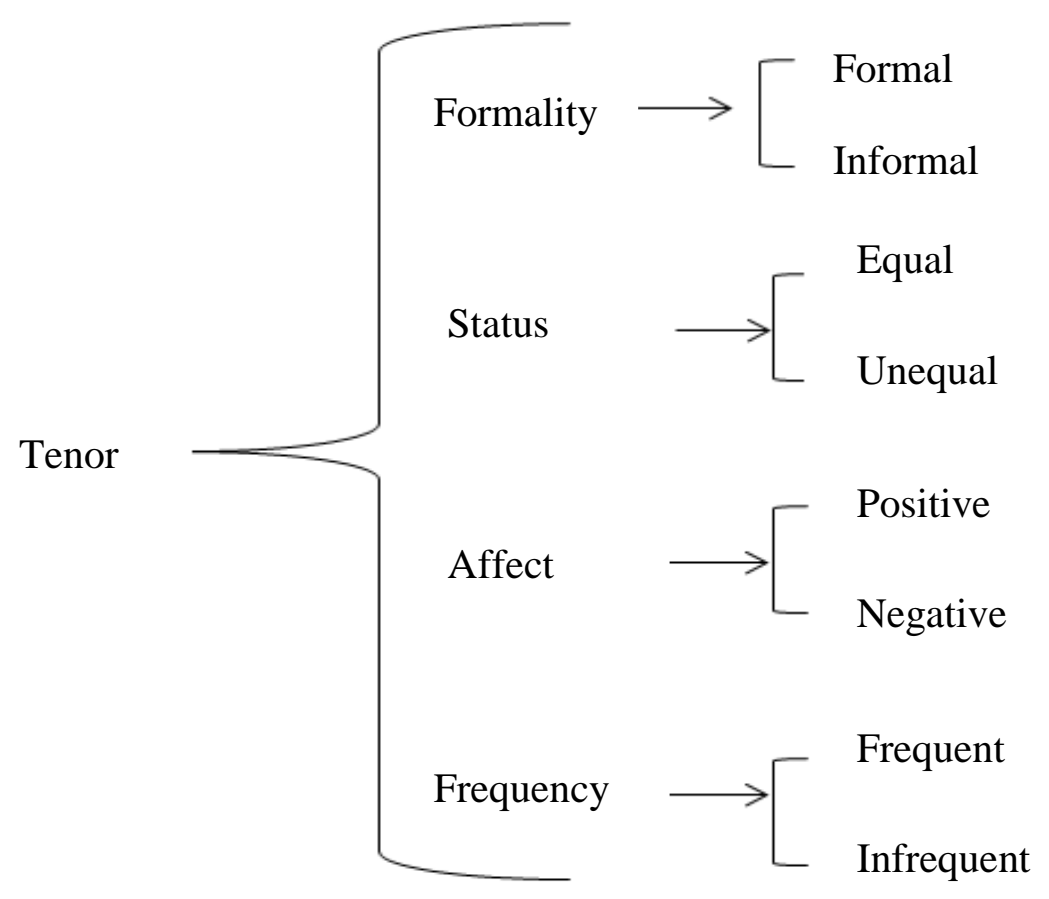

The System Network of Tenor Adopted from (Saragih:2014)

The transcripts of Hillary Clinton and Bernie Sanders' campaign speeches afterward were analyzed and classified into sixteen potential tenor configurations, they are;

1. [Formal/Equal/Positive/Frequent] 
2. [Formal/Equal/Positive/Infrequent]

3. [Formal/Equal/Negative/Frequent]

4. [Formal/Equal/Negative/Infrequent]

5. [Formal/Unequal/Positive/Frequent]

6. [Formal/Unequal/Positive/Infrequent]

7. [Formal/Unequal/Negative/Frequent]

8. [Formal/Unequal/Negative/Infrequent]

9. [Informal/Equal/Positive/Frequent]

10. [Informal/Equal/Positive/Infrequent]

11. [Informal/Equal/ Negative/Frequent]

12. [Informal/Equal/ Negative/Infrequent]

13. [Informal/Unequal/Positive/Frequent]

14. [Informal/Unequal/Positive/Infrequent]

15. [Informal/Unequal/Negative/Frequent]

16. [Informal/Unequal/Negative/Infrequent]

Out of sixteen potential tenor configurations, five were employed in the text. The following are examples of each of the configuration employed.

\section{(1) $[$ Formal/Equal/Positive/Frequent $]$}

Bernie Sanders in Vermont: I also want to thank my family: My wife Jane, my brother Larry, my children Levi, Heather, Carina and Dave for their love and support, and my seven beautiful grandchildren - Sonny, Cole, Ryleigh, Grayson, Ella, Tess and Dylan who provide so much joy in my life. 
a) The formality aspect is formal one seeing that campaign speak event is an organized meeting. It is strengthen by formal word "want to".

b) Here Bernie puts equal status to address his listeners by saying their first name “Jane, Larry, Levi, Heather, Carina and Dave".

c) The affect shown is positive, it is because of expression of praise in addressing vocatives such as “my seven beautiful grandchildren”. The praise shows Bernie feels fond towards his family.

d) The contact here is frequent in view of the fact that he speaks to his own family thus they certainly had frequent interaction before. Moreover it is strengthened by the use of nickname "Larry" instead of the full name of his brother, Lawrence Sanders.

\section{(2) [Formal/Equal/Positive/Infrequent $]$}

Hillary Clinton in Ohio: Now, I am so thrilled to be here and honestly, I could go on and on, but we have things to do. We have a lot of students here I suppose. Are we Ohio State students? How do you feel about the Buckeyes? I love it. I love it. Well what I want to tell is that as you watch the Republicans is just try to imagine for yourself, what is their vision for America?

a) The formality is formal that can be seen by the situation and with whom Hillary speaks. The situation is formal because in this event it has been determined that she would talk in front of the folks of Ohio. 
b) The status in the utterance is equal because she uses pronoun "you" and "we" indicating there is no degree between them who interact in this event.

c) Moreover affect involved in this utterance is positive. It is caused by the appearance of expressions of pleasure such as "love" and "thrilled" to show she has feeling of excitement towards the audiences.

d) As previous ones, the contact here is infrequent for it uses formal language such as "want to" which in informal way can be wanna.

\section{(3) $[$ Formal/Equal/Negative/Infrequent]}

Bernie Sanders in Vermont: This campaign is going to send a message to the billionaire class. And that is: you can't have it all. You can't get huge tax breaks while children in this country go hungry. You can't continue sending our jobs to China while millions are looking for work. You can't hide your profits in the Cayman Islands and other tax havens, while there are massive unmet needs on every corner of this nation. Your greed has got to end. You cannot take advantage of all the benefits of America, if you refuse to accept your responsibilities.

a) Formality of the utterance above is formal because the context he is talking about with her interlocutor is formal situation. Formal situation is situation that has predetermined rules before it is going on.

b) The utterance brings equal status owing to the fact that Bernie addresses people he talked to by pronoun "you". It means he does not show any differences among them in term of social status. 
c) Affect that is brought in the interaction is negative since expression of insult is used such as "your greed". The expressions show his bad feeling toward the upper class society in America that has taken advantages from their country.

d) The employed contact here is infrequent due to formal language used such as "is going to" that can be changed into gonna in slang way.

\section{(4) [Formal/Unequal/Positive/Infrequent $]$}

Hillary Clinton in New York: We also have to really focus on education. Again, that's an issue for everybody. That's why I want early childhood education for everybody. And first lady of New York City Chirlane McCray is here. I want to thank her and Mayor de Blasio for making sure that New York City has universal prekindergarten.

a) The formality of the utterance in this speech transcript is formal. It is because the situation of this event is the one with predetermined rules signing where and to whom Hillary talks have been arranged before the interaction.

b) The status appears in the utterance above is unequal because Hillary addresses her interlocutor with title such as "first lady of New York City Chirlane McCray" and "Mayor de Blasio" indicating Hillary makes herself lower than the interlocutor.

c) Moreover affect that is used there is positive because it does not employ expressions of insult but she says "thank" to them that shows she likes interacting with her interlocutors. 
d) The contact constructed here is infrequent because of the use of formal language such as "want to" that can be wanna in slang way.

\section{(5) [Formal/Unequal/Positive/Frequent $]$}

Hillary Clinton in Ohio: So in 2008, after President Obama was elected for the

first time. He asked me to come see him. I went to Chicago to see him. I didn't know why. Turns out he wanted to ask me to be secretary of state. I didn't know that at the time. But it was just the two of us. We were sitting there the first thing that came out of his mouth was: "They didn't tell us how bad it was." I said, "You know, PresidentElect, I've heard that before."

a) The situation where the interaction occurs is not an empty one. It is in formal situation because campaign speak event is formal one.

b) In term of status Hillary brings out unequal status to address someone she is talking about by using title plus name such as "President Obama" and "Mr. President-elect" because Obama was the man with highest power at the time.

c) Affect in utterance above is positive seeing that the appearance of expression of insult does not exist. In other words, there is no expression describing Hillary's bad feeling toward Barrack Obama.

d) The contact was frequent because Obama's first words "it's so much worse than they told us" signs that Hillary does familiar with pronoun 'it'. It is obviously caused by previous interaction they had before so Hillary clearly understand what "it" refers to without asking explanation from Obama. 


\section{CONCLUSIONS AND SUGGESTIONS}

\section{Conclusions}

After analyzing the data, conclusions are drawn as following.

(1) There are five kinds of tenor configurations in campaign speeches of Two

Democratic Presidential Candidates namely Hillary Clinton and Bernie

Sanders, they are [Formal/Equal/Positive/Infrequent],

[Formal/Equal/Negative/Infrequent],[Formal/Equal/Positive/Frequent],[Formal/

Unequal/Positive/Infrequent],[Formal/Unequal/Positive/Frequent].

(2) The system of tenor are realized by four elements such as:

a. Formality that is formal situation in campaign speech event.

b. Status is devided into two kinds they are equal and unequal.The equal can be seen from the use of name without title and pronoun such as you, we, Jaiza, Jeb Bush, Trump,Bill McKibben, Brenda Torpey, Ben and Jerry. Meanwhile unequal status can be seen from the use of name plus title such as Mr. President -elect, President Obama, Congresswoman Gabby Giffords.

c. Affect is devided into two parts, they are positive and negative. Positive affect is directly signed by expression of praise such as great, wonderful lineup of elected officials, my seven beautiful grandchildren, and very kind call and implicitly signed by no use of expression of insult. On the other hand negative one is signed by expression of insult such as offensive, dangerous, bigotry. 
d. Contact is devided into two parts frequent and infrequent. The infrequent contact is commonly signed by full form of expression or formal language such as let me, are going to, want to. While infrequent contact is commonly coded by pronoun such as it and that which tends to exophoric.

(3) The tenor configuration mostly used is [Formal/Equal/Positive/Infrequent] because the situation is in organizing campaign events, Hillary Clinton and Bernie Sanders deliver speeches to citizens about their programs for United States of America if they are elected as the next president. Moreover they show their thankful of being in the forum and thank people as well as persuade them to vote them in primary elections and caucuses.

\section{Suggestions}

Based on the conclusion, suggestions are staged as the following.

(1) It is suggested that the students of English Department should know how to realize a text into tenor configuration in order to reveal the participants' relationship in a discourse.

(2) It is suggested that the analysts of speeches should focus on other types of register analysis such as field and mode.

(3) It is suggested that analysts who want to do similar analysis should have deep knowledge about Systemic Functional Linguistic (SFL) in order to get vivid idea how communication can be different due to some aspects. 


\section{REFERENCES}

Ary, D., Jacobs, L.C., and Razavieh, A. 2002.Introduction to Research in Education.sixth edition New York: Wadsworth.

Dwiwibawa, F.R. and Riyanto, T. 2008. Siap Jadi Pemimpin? Latihan Dasar Kepemimpinan. Yogyakarta: Kanisius.

Eggins, S.2004. An Introduction to Systemic Functional Linguistics.second edition London: Continuum.

Halliday, M.A.K. 2002. Linguistic Studies of Text and Discourse. London: Continuum (edited by Jonathan J.Webster).

Halliday, M.A.K. and Matthiessen, C.M.I.M. 2014. Halliday's Introduction to Functional Grammar.fourth edition New York: Routledge.

Keraf, G. 2001. Komposisi: Sebuah Pengantar Kemahiran Bahasa. Flores: Nusa Indah.

Khristianto. 2010. The Participant and the Relation of Adhan Discourse as Reflected on Mosque Structure. Jurnal Leksika, 4(1), 61-72.

Martin, J.R.1992. English Text: System and Structure. Philadelphia: John Benjamins.

Meiristiani, N.2011.Understanding Tenor in Spoken Text in Year XII English Textbook to Improve theAppropriacy of the Text. Conaplin Journal,1(1), 3955 .

O'Hair, D., Rubenstein, H., and Stewart, R. 2010. A Pocket's Guide to Public Speaking.third edition New York: St Martin's.

Olii, H. 2010.Public Speaking.Jakarta: Indeks.

Perloff, R.M. 2014.The Dynamics of Political Communication: Media and Politics in Digital Age. New York: Routledge

Pfau, M., and Parrott, R. 1993. Discourse Analysis: Persuasive Communication Campaigns. Massachussets: Allyndan Bacon.

Priyanto, A. D. (2008). Tenor in Obama's speech. Solo: English Department, Fac. of Letters and Fine Arts, Sebelas Maret University. 
Rahayu, B.2014.Tenor in Indonesian University Students' Argumentative Texts Written in English. Frontiers of Language and Teaching, 5(1), 15-26.

Saragih, A.2014.Discourse Analysis: A study on Discourse Based on Systemic Functional Linguistic Theory. Medan :Unimed Press.

Saragih, A.2014.Variation and Functional Varieties of Language. Unimed, Medan (unpublished)

Song, L.2010.The Role of Context in Discourse Analysis. Journal of Language Teaching and Research, 1(6), 876-879.

Strauss, A. and Juliet, C. 2003. Dasar-dasar Penelitian Kualitatif. Yogyakarta: Pustaka pelajar offset.

Taiwo, R.2007.Tenor in Electronic Media Christian Discourse in South Western Nigeria.Nordic Journal of African Studies, 16(1), 75-89.

Thompson, G.2014. Introducing Functional Grammar.third edition London: Routledge.

Wagner, H. L. 2007. The History of the Democratic Party. New York: Chealsea House.

https://en.wikipedia.org/wiki/Bernie_Sanders accessed on 10 April 2016

https://en.wikipedia.org/wiki/Hillary_Clinton accessed on 10 April 2016

https://www.hillaryclinton.com/speeches/remarks-women-hillary-get-out-vote-event/ accessed on 9 Juni 2016

https://www.hillaryclinton.com/speeches/remarks-women-hillary-grassrootsorganizing-meeting-columbus-ohio/accessed on 9 Juni 2016

http://www.presidency.ucsb.edu/ws/index.php?pid=110221 accessed on 10 April 2016

https://www.bustle.com/articles/165581-the-transcript-of-bernie-sanders-californiaspeech-is-a-rousing-defiant-call-to-action accesed on 9 Juni 2016 